TITLE

\title{
COMPRESSIONAL STRUCTURES ON THE WEST IBERIA RIFTED MARGIN: CONTROLS ON THEIR DISTRIBUTION.
}

\section{$\underline{\text { AUTHORS }}$}

G. Péron-Pinvidic (1)

G. Manatschal (1)

S.M. Dean (2)

T.A. Minshull (2)

(1) IPGS/CGS-EOST, 1 rue Blessig, 67084 Strasbourg, France

GPP is now at: Norges Geologiske Undersøkelse (NGU), Geological Survey of Norway leiv Eirikssons vei 39, N-7491 Trondheim, Norway

Gwenn.Peron-Pinvidic@ngu.no

(2) NOC, European Way, Southampton, SO14 3ZH, UK 


\section{$\underline{\text { Abstract }}$}

The West Iberia margin is a magma-poor rifted margin that resulted from Jurassic to Cretaceous polyphase rifting leading to the opening of the North Atlantic Ocean. The Mesozoic rift structures were overprinted by two compressive tectonic events during Eocene and Miocene times resulting from collision between Iberia, Europe and Africa. The effects of these compressive tectonic events are expressed by faults and folds within the post-rift sedimentary sequence. We mapped and studied these Cenozoic deformation structures throughout the Southern Iberia Abyssal Plain $\left(40^{\circ}-41^{\circ} \mathrm{N}\right.$, $11^{\circ}-13^{\circ} \mathrm{W}$ ) on the basis of an extensive dataset of time migrated seismic profiles acquired by various academic institutions. Acoustic basement has also been analysed on the basis of its seismic aspect, in order to test potential relationships with the distribution of the post-rift sedimentary deformation.

Our observations lead to three major conclusions concerning the deformation affecting the post-rift sediments in the Southern Iberia Abyssal Plain. (1) The deformation occurs within the zone of exhumed continental mantle and not at its transition to continental or oceanic crust; (2) it is localized within a zone overlying basement with well-defined seismic characteristics; and (3) it is closely related to the major topographic features observed in the ocean-continent transition. The localization of the deformation within the zone of exhumed continental mantle and not at its boundaries to the adjacent oceanic and continental crust suggests that the limits between the different types of crust are transitional rather than sharp. Our results show that the zone of exhumed continental mantle represents the weakest domain within the margin that is preferentially deformed during initial convergence. At higher convergence rates, this zone may coincide with the location of a future subduction.

Post-rift compressional structures are well known from the northwest European margins and their formation has been attributed to various causes, such as changes in seafloor-spreading geometry, ridge push forces affecting pre-existing crustal weaknesses, major changes in plate motions, influence of the Alpine collision, or influence of the Iceland Plume (Lundin \& Doré 2002). In contrast, compressional structures on the West Iberia margin have received less attention, despite the extensive investigations of this margin in the last three decades. Seismic surveys and deep sea drilling (e.g. ODP Legs 103, 149 and 173) along this margin and in particular in the Southern Iberia Abyssal Plain, have revealed the existence of a transitional domain up to $160 \mathrm{~km}$ wide that formed at the end of magma-poor and polyphase rifting during late Jurassic to early Cretaceous time. However, because all ODP drill sites $(897,899,1068,1069,1070)$ targeted structural highs, and because the interpretation of geophysical data is often ambiguous, the internal structure and composition of the ocean-continent transition is at present still debated.

An alternative approach to analyse the internal structure of the ocean-continent transition is to study how this zone behaved during Cenozoic compression. Inherited heterogeneities within the basement, defined either by compositional, thermal and/or structural variations, are likely to control the distribution of deformation during compression and would tend to localize deformation. Thus, the distribution of deformation structures related to reactivation can give insights into the rheological behaviour and indirectly into the internal structure and nature of the ocean-continent transition and its boundaries with the adjacent continental and oceanic crusts. In order to test this conceptual idea, deformation structures related to the Cenozoic compression in the post-rift sediments were mapped and their distribution compared with the distribution of basement domains, distinguished by specific seismic character. Our results show an interesting correlation between the distribution of deformation structures in the post-rift sediments and the mapped basement domains, which will be discussed later. 


\section{Tectonic Setting}

The Iberia margin is a magma-poor passive margin situated offshore Spain and Portugal. It extends over $800 \mathrm{~km}$ from Cap Finistere in the North $\left(\sim 43^{\circ} \mathrm{N}\right)$ to Cap Sao Vincente in the South $\left(\sim 37^{\circ} \mathrm{N}\right)$. It results from continental rifting and early Cretaceous breakup of North America and Iberia/Europe which led to the opening of the southern North Atlantic Ocean.

Three segments, easily identifiable on a bathymetric map (Fig. 1), can be defined through the Iberia margin: the Galicia Margin (or Deep Galicia Margin) in the north, the Tagus Abyssal Plain in the south and the Southern Iberia Abyssal Plain in the centre.

The tectonic history of the Iberia margin is complex. Following the tectonics of the Variscan orogeny, the area underwent the effects of three major episodes of rifting and two phases of post-rift compression. While the compressional events are well dated (Eocene and Miocene), the precise ages of the rifting episodes are less well constrained. Pinheiro et al. (1996) proposed a late Trias to early Jurassic age for the first phase of rifting, followed by an Oxfordian to early Kimmeridgian phase and finally a Valanginian/Hauterivian to late Aptian phase. The structural architecture acquired by the margin during these events is characterized by series of tilted basement blocks bounded by normal faults and by zones of more irregular, flat topography and by peridotite ridges, referred here as the ocean-continent transition. The nature of this domain has been studied by numerous geophysical and geological surveys (magnetic, gravity, and seismic surveys; ODP Legs 103, 149 and 173). Despite all the available data, the origin, formation and nature of the oceancontinent transition basement remain controversial. In the past, three hypotheses have been discussed:

\section{1) The hypothesis of the ultra-slow spreading oceanic crust}

Sawyer (1994) and Whitmarsh \& Sawyer (1996) suggested that the ocean-continent transition in the Southern Iberia Abyssal Plain is oceanic crust formed in an ultra - slow spreading environment, with an accretion rate of about 6.3 to $5 \mathrm{~mm}$ /year (half spreading rate). They argued that none of the rocks drilled during Leg 149 was of continental origin, an argument subsequently proved wrong, since the gabbros drilled at Site 900 are of Paleozoic age and therefore continental (Manatschal et al. 2001). Whitmarsh \& Sawyer (1996) compared the common occurrence of drilled serpentinised mantle peridotites with ultra slow spreading systems, where mantle rocks are exposed at the seafloor (Cannat 1993). The hypothesis of ultra-slow spreading oceanic crust is also incompatible with magnetic data. In the Southern Iberia Abyssal Plain, the magnetic anomalies are weak and very few linear anomalies are identified; Whitmarsh \& Miles (1995) were unable to model these as seafloor-spreading anomalies.

\section{2) The hypothesis of the thinned, disrupted and intruded continental crust}

Other studies suggested that the ocean-continent transition is thin continental crust that has been faulted and intruded by magmatic bodies during rifting (Whitmarsh et al. 1990a ; Whitmarsh \& Miles 1995 ; Whitmarsh \& Sawyer 1996). The development of this hypothesis came from the analysis of magnetic anomalies. Based on a suggestion that breakup propagated northwards, Whitmarsh \& Miles (1995) proposed that the magnetic anomalies can be explained by syn-rift magmatic intrusions into highly thinned continental crust. This model was able to explain the wideangle seismic observations of Whitmarsh et al. (1990b). However, more recent seismic refraction experiments revealed that the ocean-continent transition is made of a $\sim 4 \mathrm{~km}$-thick lower layer with high velocities $(\sim 7.6 \mathrm{~km} / \mathrm{s})$ and a 2 to $4 \mathrm{~km}$-thick upper layer with lower velocities $(4.5-7 \mathrm{~km} / \mathrm{s})$ (Chian et al. 1999; Dean et al. 2000), neither of which is interpreted as continental in origin.

\section{3) The hypothesis of exhumed serpentinised peridotites}

The third hypothesis is that the ocean-continent transition consists of serpentinised peridotite resulting from the exhumation of lithospheric mantle, perhaps accompanied by melt intrusions 
(Beslier et al. 1996 ; Pickup et al. 1996 ; Discovery 215 Working Group 1998 ; Chian et al. 1999 ; Dean et al. 2000). This hypothesis arises from the analysis of seismic velocity models and from drilling results (Legs 103, 149, 173). The ocean-continent transition has particular seismic velocity patterns that are interpreted as representative of serpentinised peridotites: the upper $\sim 2-4 \mathrm{~km}$ layer is interpreted to represent highly serpentinised peridotites (up to 100\%) and the underlying velocity gradient suggests the decrease in degree of serpentinisation with depth (Discovery 215 Working Group 1998 ; Chian et al. 1999 ; Dean et al. 2000).

At present, the hypothesis favoured by the scientific community is the third one. Whitmarsh et al. (2001) introduced the term "zone of exhumed continental mantle" to describe the most likely nature of the deep Iberia ocean-continent transition. However, for the conjugate Newfoundland margin the composition of the basement in transition zone is still debated (see Hopper et al. 2003; Shillington et al. 2006 ; Lau et al. 2006).

\section{Deformation structures in the post-rift sediments}

In the Southern Iberia Abyssal Plain, six seismic units have been defined by Wilson et al. (1996) and partly redefined by Péron-Pinvidic et al. (2007). The six units are characterised by reflectors and packages of reflectors that present the same seismic characteristics through the area. Correlations with lithological units defined at the boreholes of ODP Legs 149 and 173 (Sawyer, Whitmarsh, Klaus et al. 1994; Whitmarsh, Beslier, Wallace et al. 1998) were made in order to define the lithologies, their depositional environments and the age of the units (Péron-Pinvidic et al. 2007). Figure 2 illustrates the six seismic units and shows their distributions in a schematic transect across the Southern Iberia Abyssal Plain.

\section{Mapped deformation structures}

Deformation structures such as folds and faults are observed within seismic Units C and D in the Southern Iberia Abyssal Plain but do not affect Unit E, which dates the deformation as approximately mid to late Miocene (Péron-Pinvidic 2006). This age suggests that the deformation was contemporaneous with the compression of the Betic domain in southern Spain and the Gulf of Cadiz (Maldonado et al. 1999) that resulted from the collision with the African plate. Another older event is dated as Eocene (Masson et al. 1994) and is linked with the formation of the PyreneanCantabrian chain forming the northern limit of the Iberian micro plate. This event is, however, better recorded in the Deep Galicia Margin, whereas in our study area, the Miocene event is more dominant.

In the post-rift sediments, three types of deformation structures can be seen. These are shown in Figure 3 and consist of faults (mainly reverse faults, but normal faults occur as well), folds above basement highs and folds above flat basement.

Among the mapped deformation structures, normal faults were observed in some seismic sections (CAM142, CAM151 and CAM153). Unless these normal faults were formed by sedimentary compaction, this observation may be surprising in the context of compressional tectonics. However, we believe that their presence indicates that the direction of compression was oblique to the margin rather than strictly perpendicular. De Paola et al. (2005) investigated inversion structures traditionally analysed as due to local or regional crustal shortening. They found that such compressional structures could also be formed by progressive and partitioned transtension. Therefore, it is possible that the post-rift compressive structures observed within the Southern Iberia Abyssal Plain have formed by an oblique convergence that might also lead to local normal faulting. 


\section{Distribution of deformation structures in the Southern Iberia Abyssal Plain}

On the basis of the Sonne and Lusigal seismic lines, Masson et al. (1994) described the sedimentary deformation within the Southern Iberia Abyssal Plain as "series of en echelon segments, with $a$ consistent eastward offset between segments towards the south". However, such en echelon structures are not evident in our more comprehensive dataset. Two zones of deformation can be distinguished, one west and the other east of profile CAM132 (Fig. 3). To the west, numerous deformation structures are observed, spanning all the defined categories, and can be followed along strike between profiles (e.g. faults in the western parts of profiles CAM142, 151 and 153 (Fig. 3)). The $010^{\circ}-025^{\circ} \mathrm{N}$ strike of these faults mimics the trend of the underlying basement highs (Fig. 4). In contrast, deformation structures in the eastern zone are rare and less well developed and can not be traced over large distances.

Comparing the locations of deformation structures with a basement contour map allows seven zones to be identified. They are labelled 1 to 5, PR3 and PR4 in Figure 4. The zones labelled PR3 and PR4 correspond to the peridotite ridges R3 and R4 described by Beslier et al. (1993), Pickup et al. (1996) and Dean et al. (2000).

\section{Zones PR3 and PR4 (Peridotite Ridges)}

Peridotite ridge $P R 3$ has been described as an almost north-south linear continuous basement structure (Beslier et al. 1993). However, our observations do not support such a continuous structure. In reality this zone corresponds to an alignment of different independent basement morphologies, linking an elevated symmetric block in the north to flatter and more massive structures towards the south. Each block of PR3 is associated with deformation structures.

Peridotite ridge PR4 has been described as extending from the basement high drilled at ODP Site 898 in the north to the south-western part of the Southern Iberia Abyssal Plain (Pickup et al. 1996; Dean et al. 2000) (Fig. 4). However, like in the case of PR3, this structure does not correspond to a continuous feature. Sedimentary wedges of Unit E above Unit D are observed to occur in the north.

\section{Zones 1 to 5}

Zone 1 is comparable to PR3. It corresponds in our study area to a topographic alignment of different basement highs, from a symmetric structure likely to be a peridotite ridge on profile CAM144 to flatter and more massive highs to the south. Fault structures are consistently observed to be associated with these basement highs.

Zone 2 is located between PR3 and PR4. It displays widespread deformation structures including faults and folds of varying amplitude. This deformation is associated with particularly irregular basement topography. In profiles CAM142 and CAM151 there are large folds that are not directly linked with a basement structure occurring over an almost flat basement.

Zone 3 located to the south of PR4 displays numerous fold structures of variable length and shape above irregular basement morphology.

Zone 4 corresponds to the north-eastern part of the Southern Iberia Abyssal Plain where basement topography is characterised by major tilted blocks, deep basins and strong reflectors within the basement. Here, deformation structures are rare. However, within the basin bordering the basement block at ODP Site 901 (Fig. 5), strong reflections corresponding to the base of Unit $\mathrm{C}$ and to the upper part of Unit B are folded and onlapped by reflectors belonging to the upper part of Unit $\mathrm{C}$ and to the overlying Unit D. Because deeper reflectors are not affected, we prefer to interpret this structure as the result of deep currents that were localized at the foot of the margin within fault 
bounded grabens, an interpretation which is compatible with more regional studies of this structure (Reston, Pers. comm. 2005).

Zone 5 corresponds to the south-eastern part of our study area. In this zone the basement deepens towards the South without marked topography and deformation structures.

A correspondence between basement topography and the distribution of deformation structures is clear within the western zone where the major alignments of basement highs seem to control the distribution of the deformation structures (zones 1 and PR3). West of profile CAM132 almost all basement highs are associated with sedimentary deformation. This observation suggests that these structures were reactivated during the compressive Cenozoic phase and caused folding and/or faulting of the overlying sediments. Sibuet et al. (1996) described a normal fault bordering the eastern flank of PR3 on profile Lusigal04. They interpreted this structure to be reactivated as a reverse fault during lower Miocene, leading to deformation of the overlying sedimentary sequences. We were not able to identify such a reactivated structure through our dataset: in the western Southern Iberia Abyssal Plain no clear reflectors have been identified that either bound these highs or underlie them. Within the central and the eastern part of the area, the distribution of deformation structures is less widespread. There is no deformation above each basement high, like that seen in the western zone. The key question is therefore what controls the distribution of the deformation in the Southern Iberia Abyssal Plain.

\section{Sedimentary deformation in the Bay of Biscay and Porcupine Basin}

Deformation structures similar to those observed in the Southern Iberia Abyssal Plain are also described from other areas along the NW European Atlantic margin. Montadert et al. (1979) and Masson \& Parson (1983) studied the northern continental margin of the Bay of Biscay and the southern Porcupine Basin respectively. They described complex zones of faulting and folding confined to elongated narrow belts more or less coincident with the location of the ocean-continent transition. These observations suggest that the occurrence of deformation structures in the post-rift sediments overlying the zone of exhumed continental mantle, as observed in the Southern Iberia Abyssal Plain, may be a more general feature of magma-poor rifted margins and ultimately may be used as a finger print to localize the zone of exhumed continental mantle within the ocean-continent transition.

\section{Seismic character of the acoustic basement}

The broad coverage and consistent acquisition and processing parameters of the CAM seismic profiles enabled us to analyse the variation of the seismic reflection character of acoustic basement across the Southern Iberia Abyssal Plain. In this study, basement corresponds to the acoustic domain underlying the layered sedimentary cover. It may correspond to either crustal, mantle or magmatic material, potentially covered by pre-rift sediments in the continental part.

An initial study by Dean (1999) defined three distinct reflective characters ("unreflective”, "layered reflective" and "reflective" basement) that led him to identify four regions within the Southern Iberia Abyssal Plain. We have refined his approach by adding more criteria to define five acoustic basement domains (named I to V; Fig. 6). The criteria used in our study are: (1) seismic character of top of basement (chaotic, continuous or not, easily identifiable or not); (2) sedimentary onlaps onto top basement and clarity of these onlap relationships; (3) topography (flat or characterized by tilted blocks); (4) the presence of reflectors within the basement; (5) the dimensions of the tilted basement blocks if present and (6) the seismic character of the underlying basement (transparent or chaotic, 
more or less reflective). These domains were mapped through the CAM seismic lines (Fig. 6). We then interpolated the domain boundaries between these profiles, checking them on the Sonne, ISE, IAM9 and LG12 lines.

\section{Basement domains identified in the Southern Iberia Abyssal Plain}

Basement domain I is mainly characterized by large angular tilted basement blocks bordered by high amplitude, continuous listric reflectors interpreted as detachment faults. Basement reflectivity is chaotic and dominated by the presence of numerous reflectors of varying length, depth, dip and amplitude. Some of these are interpreted as faults and detachment faults. The top of the basement is difficult to define precisely: it is marked by a chaotic and discontinuous reflector with low amplitude. Sedimentary onlaps are also poorly imaged and difficult to identify.

Basement domain II also displays basement blocks, but with a distinct geometry from those of domain I. They are smaller and flatter. Unlike domain I, no clear reflectors are observed bordering the blocks and penetrating the basement. Numerous reflectors are observed within the basement, but they are not obviously linked with the formation of the blocks. The top of basement is better defined than in domain I. It corresponds to a discontinuous reflector with moderate to high amplitude. Sedimentary onlaps are clearly identifiable where the top basement reflector is continuous. The reflection character of the basement is still chaotic and cut by numerous reflections.

Basement domain III is characterized by irregular basement topography. No large blocks or tilted blocks are observed. Reflectors are still present within the basement but far less numerous and are often close to the surface. The top of basement is very difficult to define and is often difficult to distinguish from the overlying sediments. Therefore, the identification of sedimentary onlaps poses problems. The seismic character of the basement is chaotic and transparent.

Basement domain IV is defined by uniform basement reflection character, rough with medium amplitude and with rare reflections which are always located close to top basement. There are blocks, but without any bordering or underlying reflectors. The top of basement is clear, marked by high amplitude, relatively continuous reflector. Sedimentary onlaps are well defined. Two subdomains are seen, a northern one ( $\mathrm{IV}_{\text {north) }}$ and a southern one ( $\left.\mathrm{IV}_{\text {south }}\right)$.

Basement domain $V$ is characterized by a discontinuous and chaotic top basement reflector often poorly defined. Sedimentary onlaps are also difficult to identify. Basement blocks are observed, from elevated symmetric structures to lower, larger and asymmetric ones. No internal reflections were identified. The basement in this domain is more reflective than in domain IV.

\section{$\underline{\text { Relationship between basement domains and geophysical and geological attributes }}$}

\section{$\underline{\text { Seismic refraction }}$}

Wide-angle seismic profiles (Chian et al. 1999; Dean et al. 2000) have revealed strong lateral variations in the velocity and velocity gradient at the top of basement across the Southern Iberia Abyssal Plain. These variations appear to correspond well with variations in acoustic basement character (Fig. 7). The velocity at the top of basement is $\sim 4.5 \mathrm{~km} / \mathrm{s}$ in domain $\mathrm{I}, \sim 5.0-5.3 \mathrm{~km} / \mathrm{s}$ in domain II, $\sim 3.8-4.7 \mathrm{~km} / \mathrm{s}$ in domain III, and $\sim 5 \mathrm{~km} / \mathrm{s}$ in domains IV and V.

\section{Reduced to the pole magnetic anomalies}

Russell \& Whitmarsh (2003) published a reduced-to-the-pole magnetic anomalies chart revealing various magnetic features through the West Iberia margin. Correlations between basement domains 
limits and the reduced-to-the-pole magnetic anomalies chart are not obvious. The southern part of Southern Iberia Abyssal Plain does not exhibit any clear correlation, except domain $\mathrm{V}$ that corresponds to the largest negative magnetic anomaly of the area (-250nT). However, in the northern part, along the drilled transect, the limits of the basement domains correspond to some of the magnetic features (Fig. 8). Relatively high amplitude anomalies $(+150 \mathrm{nT})$ characterize domain I. Domain II is associated with low anomalies (-100nT). Domain III corresponds to a positive large anomaly (+50nT) over drilled Sites 899 and 898, and domains $\mathrm{IV}_{\text {north }}$ and V correspond to the first magnetic anomaly commonly identified as oceanic (M3; Whitmarsh \& Miles 1995).

\section{Drilled lithologies}

The comparison between defined basement domains and drilled lithologies shows that continental and exhumed mantle domains can be distinguished: the pre-rift sediments underlain by upper continental rocks (Site 1065) correspond to domain I; exhumed crust (Sites 900 and 1067) and continental allochthons overlying exhumed mantle (1068 and 1069) correspond to domain II; and serpentinised peridotites (Site 1070, 897 and 899) correspond to basement domains III, IV and V. The mantle rocks drilled at ODP Site 1070, 897 and 899 are quite different in detail. At Site 897 the entire ultramafic section is extensively serpentinised and exhibits a transition from carbonate-rich serpentinite associated with serpentinite breccias at the top (e.g. ophicalcite) to massive serpentinised peridotite, locally displaying plagioclase and clinopyroxene enriched zones down hole. At Site 899 ultramafic rocks were found in breccias and as olistoliths of serpentinised peridotite several tens of meters across, intercalated in sediments. The ultramafic clasts and olistoliths that may derive from the adjacent basement have a large compositional range from plagioclase-bearing peridotites to pyroxene- and olivine-rich peridotites. Up to $30 \%$ plagioclase occurs in patches or veinlets in the peridotites or rims the spinel. At Site 1070 massive serpentinised mantle rocks containing gabbro pegmatites are overlain by a poorly sorted, clast supported breccia which consists of serpentinised peridotite and gabbro clasts that are cemented by blocky calcite. At the contact between these "ophicalcites" and the massive serpentinised mantle, serpentine gouge was observed. The underlying serpentinised peridotite varies in composition between pyroxene-rich and -poor layers and has a weak, shallowly dipping high-T foliation. It remains unclear whether compositional variations, (plagioclase-bearing lherzolite occurs at Sites 897 and 899 but is absent at Site 1070) or the occurrence of a tectono-sedimentary cover sequence formed by breccias and/or ophicalcite can explain the seismic facies differences between basement domains III, IV and V. In any case, the mantle drilled in the Southern Iberia Abyssal Plain appears to be rather heterogeneous throughout the zone of exhumed continental mantle.

\section{$\underline{\text { Discussion }}$}

The internal structure of the ocean-continent transition at magma poor rifted margins is at present poorly known. The aim of this paper was to explore, based on mapping of basement domains and of the distribution of deformation structures in the overlying post-rift sediments, how this zone behaved during subsequent Cenozoic compression. We believe that inherited heterogeneities within the basement, defined either by compositional, thermal and/or structural variations, may control the distribution of deformation during compression. Therefore, we expected to see localization of the deformation in the case of strong heterogeneities and more distributed deformation in the case of a very homogeneous zone of exhumed continental mantle. Moreover, in the case of abrupt lithological contacts at the boundaries between this zone and the adjacent continental and oceanic crust, deformation structures would be expected to occur at the limits of the zone, whereas if the boundaries correspond to gradual transitions, the deformation would not necessarily coincide with these limits. 
The results of our mapping show an interesting correlation between the distribution of deformation structures in the post-rift sediments and mapped basement domains corresponding to lithologically defined parts of the margin. Domain I corresponds to the thinned continental distal margin; domains III to V to the zone of exhumed continental mantle; and domain II to a transition between these regions. This correspondence between the mapped basement domains and the location of post-rift sedimentary deformation is suggested by a comparison of Figures 3 and 6. Deformation structures in the post-rift sediments occur mainly within basement domains III, IV and V, with a clear concentration within IV and V (Fig. 9). Deformation structures that occur outside of these domains are rare. These are reverse faults that slightly affect some reflectors of Unit C above Site 1069 basement block and above another block along profile CAM147 (domain II) together with an asymmetrical fold north of Hobby High visible on ISE lines 28 and 29 at the limit between domains I and II.

The observed correlation between basement domains and deformation structures in the overlying post-rift sediments illustrates that deformation is localized in the zone of exhumed continental mantle and not at its boundaries. Therefore the boundaries between the zone of exhumed continental mantle and the adjacent continental and oceanic crust are likely to be transitional and strong relative to the zone itself. The concentration of deformation along aligned basement highs indicates that the highs correspond to regions of crustal weakness that are related to inherited structures and/or lithological variations. These observations have two major implications: one concerns the characterisation and description of the zone of exhumed continental mantle in magmapoor margins and the second the reactivation and onset of subduction during the transition from passive to active margins:

\section{Characterisation of the zone of exhumed continental mantle in magma-poor margins}

Although at present the existence of a zone of exhumed continental mantle is only confirmed for the Iberia margin (the only deep magma-poor margin where drilling penetrated basement), geophysical evidence suggests that such zones are more wide spread and occur at many margins. Thinon (1999) suggested the existence of exhumed mantle in the Amorican margin and Bullock \& Minshull (2005) for the Goban Spur. Interestingly, deformation structures similar to those observed in the Southern Iberia Abyssal Plain are also described from the NW European Atlantic margins. As mentioned above, Montadert et al. (1979) and Masson \& Parson (1983) studied the northern continental margin of the Bay of Biscay and the southern Porcupine Basin where they identified post-rift deformations more or less coincident with an area showing the seismic characteristics of a zone of exhumed continental mantle. These observations suggest that the occurrence of deformation structures in the post-rift sediments in this zone, as observed in the Southern Iberia Abyssal Plain, may be a more general feature of magma-poor rifted margins and may be used as an indicator for locating exhumed mantle within an undrilled ocean-continent transition.

\section{Reactivation and onset of subduction during the transition from passive to active margins}

How passive margins are reactivated and ultimately evolve into an active margin with a subduction zone is poorly understood. The Southern Iberia Abyssal Plain shows the incipient stage of compression, which allows us to see were deformation localized first and consequently to define the weakest zone within the margin. In the case of the Southern Iberia Abyssal Plain, one would expect, if convergence had continued, that shortening would have localized in the zone of exhumed continental mantle and finally led to the formation of a subduction zone. Unfortunately, we cannot test this hypothesis for the Iberia margin. However, we can look for evidence of this process in the ancient margins in the Alps that are commonly considered as analogues to Iberia type margins (see 
Manatschal 2004 and references therein). In the case of the Alpine margins, the remnants of the distal margins and the zone of exhumed continental mantle are well preserved and may correspond, like the Iberia margin, to the lower plate margin (based on the terminology of Lister et al. 1986). In the reconstruction of the former rifted margins in the Alps, the transition to more oceanward parts of the zone of exhumed continental mantle are however not preserved except for some particular examples (e.g. Chenaillet massif, French Alps). Most of the ophiolites in the Alps that show some more oceanic characteristics (Lagabrielle \& Lemoine 1997) are overprinted by high pressure metamorphism (blue schist to eclogite facies) indicating subduction pathways. Thus, in the Alps, the subduction had to start in the zone of exhumed continental mantle, explaining that the more continental parts of this zone are still preserved, belonging to the hanging wall of the subduction (e.g. Platta and Err nappes; Manatschal \& Nievergelt 1997) while more oceanward parts together with the oceanic crust were subducted. Based on observations from the Alps and Iberia, we believe that the zone of exhumed continental mantle is the weakest part in magma-poor margins and represents the location where the subduction may have localized at the transition from a passive to an active margin.

\section{Conclusions}

The aim of this study was to investigate whether there is a direct relationship between the distribution of compressional structures in post-rift sediments in the Southern Iberia Abyssal Plain and the nature of underlying basement domains that were defined using a number of geophysical and geological attributes. The results show that deformation structures are localized preferentially within the zone of exhumed continental mantle and not at the boundaries with continental or oceanic crust. This key observation enables us to draw three major conclusions:

1) the boundaries of the zone of exhumed continental mantle with the adjacent continental and oceanic crust are not reactivated, suggesting that they are transitional rather than sharp lithological contacts;

2) the zone of exhumed continental mantle is heterogeneous and represents the weakest part of the distal margin and therefore a preferred location for the initiation of subduction;

3) mapping of deformation structures in post-rift sediments is an indirect way to determine the nature of the underlying basement and may be used as a fingerprint to locate the exhumed mantle in the deep parts of weakly reactivated magma-poor rifted margins.

\section{Acknowledgements}

This work was supported by the Royal Society through a Joint Project Grant. GM and GPP thank the GDR Marges. GPP thanks the EU and the Marie Curie grant program. We also wish to thank I.Walker and R.Gatliff for comments, suggestions and constructive reviews.

\section{$\underline{\text { References }}$}

Beslier, M.O., Ask, M. \& Boillot, G. 1993. Ocean-continent boundary in the Iberia Abyssal Plain from multichannel seismic data. Tectonophysics 218, 383-393.

Beslier, M.O., Cornen, G. \& Girardeau, J. 1996. Tectono-metamorphic evolution of peridotites from the ocean/continent of the Iberia Abyssal Plain margin. In: Whitmarsh R.B., Sawyer D.S., Klaus A. 
and Masson D.G. (Eds.), Proceedings of the Ocean Drilling Program, Scientific Results, 149, 397412.

Bullock, A.D. \& Minshull, T.A. 2005. From continental extension to seafloor spreading: crustal structure of the Goban Spur rifted margin, southwest of the UK. Geophysical Journal International 163-2, 527-546.

Cannat, M. 1993. Emplacement of mantle rocks in the seafloor at Mid-Ocean Ridges. Journal of Geophysical Research 98-B3, 4163-4172.

Chian, D., Louden, K., Minshull, T.A. \& Whitmarsh, R.B. 1999. Deep structure of the oceancontinent transition in the southern Iberia Abyssal Plain from seismic refraction profiles: Ocean Drilling Program (Legs 149 and 173) transect. Journal of Geophysical Research 104-B4, 74437462.

De Paola, N., Holdsworth, R.E., McCaffrey, K.J.W. \& Barchi, M.R. 2005. Partitioned transtension: an alternative to basin inversion models. Journal of Structural Geology 27-4, April 2005, 607-625.

Dean, S.M. 1999. Structure of the ocean-continent transition in the southern Iberia Abyssal Plain. $\mathrm{PhD}$ thesis, Robinson College, Cambridge.

Dean, S.M., Minshull, T.A., Whitmarsh, R.B. \& Louden, K.E. 2000. Deep structure of the oceancontinent transition in the southern Iberia Abyssal Plain from seismic refraction profiles: the IAM-9 transect at 40²0'N. Journal of Geophysical Research 105-B3, 5859-5885.

Discovery 215 Working Group (Minshull, T. A., Dean, S. M., Whitmarsh, R. B., Russell, S. R., Louden, K. E. \& Chian, D.) 1998. Deep structure in the vicinity of the ocean-continent transition zone under the southern Iberia Abyssal Plain. Geology 26, 743-746.

Groupe Galice 1979. The continental margin off Galicia and Portugal : acoustical stratigraphy, dredge stratigraphy, and structural evolution. In : Sibuet, J.C., Ryan W.B.F. et al., Initial Reports DSDP, 47 (Pt.2), Washington (U.S. Govt. Printing Office), 633-662.

Henning, A.T., Sawyer, D.S. \& Templeton D.C. 2004. Exhumed upper mantle within the oceancontinent transition on the northern West Iberia margin: evidence from prestack depth migration and total tectonic subsidence analyses. Journal of Geophysical Research 109-B5, B05103, doi:10.1029/2003JB002526.

Hopper, J.R., Funck, T., Tucholke, B.E., Larsen, H.C., Holbrook, S., Louden, K., Shillington, D. \& Lau H. 2004. Continental breakup and the onset of ultra-slow seafloor spreading off Flemish Cap on the Newfoundland rifted margin. Geology 32, 93-96.

Lagabrielle, Y. \& Lemoine M. 1997. Alpine, Corsican and Apennine ophiolites: the slow-spreading ridge model. Comptes Rendus de l'Académie des Sciences, Series IIA, Earth and Planetary Science, Volume 325, Issue 12, December 1997, 909-920.

Lau, H.K.W., Louden, K.E., Funck, T., Tucholke, B.E., Holbrook, W.S., Hopper, J.R. \& Larsen H.C. 2006. Crustal structure across the Grand Banks - Newfoundland Basin Continental margin - I. Results from a seismic refraction profile. Geophysical Journal International 167, 127-156.

Lister, G.S., Etheridge, M.A. \& Symonds P.A. 1986. Detachment faulting and the evolution of passive continental margins. Geology 14, 246-250. 
Lundin, E. \& Dore, A.G. 2002. Mid-Cenozoic post-breakup deformation in the 'passive' margins bordering the Norwegian-Greenland Sea. Marine and Petroleum Geology 19-1, 79-93.

Maldonado, A., Somoza, L. \& Pallares, L. 1999. The Betic orogen and the Iberian - African boundary in the gulf of Cadix: geological evolution (central North Atlantic). Marine Geology 155, 9-43.

Manatschal, G. \& Nievergelt, P. 1997. A continent-ocean transition recorded in the Err and Platta nappes (Eastern Switzerland). Eclogae Geologicae Helvetiae 90-1, 3-27.

Manatschal, G., Froitzheim, N., Rubenach, M. \& Turrin, B.D. 2001. The role of detachment faulting in the formation of an ocean-continent transition: insights from the Iberia Abyssal Plain. In: Wilson R.C.L., Whitmarsh R.B., Taylor B. and Froitzheim N., 2001. Non-volcanic rifting of continental margins: a comparison of evidence from land and sea. Geological Society, London, Special Publications, 187, 1-24.

Manatschal, G. 2004. New models for evolution of magma-poor rifted margins based on a review of data and concepts from West Iberia and the Alps. International Journal of Earth Sciences 93, 432466.

Masson, D.G. \& Parson, L.M. 1983. Eocene deformation on the continental margin SW of the British Isles. Journal of the Geological Society, London, 140, 913-920.

Masson, D.G., Cartwright, J.A., Pinheiro, L.M., Whitmarsh, R.B., Beslier, M.O. \& Roeser, H. 1994. Compressional deformation at the ocean-continent transition in the NE Atlantic. Journal of the Geological Society, London, 151, 607-613.

Montadert, A., Roberts, D.G., De Charpal, O. \& Guennoc P. 1979. Rifting and subsidence of the northern continental margin of the Bay of Biscay. In: Montadert, L. \& Roberts, D.G. (eds) Initial Reports of the Deep Sea Drilling Project, 48, Washington (U.S. Government Printing Office), 10251060.

Péron-Pinvidic, G. 2006. Morphotectonique et architecture sédimentaire de la Transition OcéanContinent de la marge Ibérique. PhD thesis, Louis Pasteur University of Strasbourg, France, 300p.

Péron-Pinvidic, G., Manatschal, G., Minshull, T., and Sawyer, D. 2007. The tectono-sedimentary and morpho-tectonic evolution recorded in the deep Iberia-Newfoundland margins: evidence for $a$ complex break-up history. Tectonics. Doi:10.1029/2006TC001970.

Pickup, S.L.B., Whitmarsh, R.B., Fowler, C.M.R. \& Reston T.J. 1996. Insight into the nature of the ocean-continent transition off West Iberia from a deep multichanel seismic reflection profile. Geology 24, 1079-1082.

Pinheiro, L.M., Wilson, R.C.L., Pena Dos Reis, R., Whitmarsh, R.B. \& Ribeiro, A. 1996. The western Iberia margin: a geophysical and geological overview. In: Whitmarsh, R.B., Sawyer, D.S., Klaus, A. \& Masson, D.G. (eds) Proceedings of the Ocean Drilling Program, Scientific Results 149, 3-21.

Roeser, H.A., Eilers, G., Fritsch, J., Keppler, H., Kewitsch, P., Klein, A., Pinheiro, L. \& Schreckenberger, B. 1992. SONNE Cruise S0-75 : Geophysical investigations of the crustal 
structure of the North Atlantic off Portugal, final report of the geophysical legs of the SONNE cruise SO-75, 14 October 1991 - 12 November 1991.

Russell, S.M. \& Whitmarsh, R.B. 2003. Magmatism at the west Iberia non-volcanic rifted continental margin: evidence from analyses of magnetic anomalies. Geophysical Journal International 154, 706-730.

Sawyer, D.S. 1994. The case for slow-spreading oceanic crust landward of the peridotite ridge in the Iberia Abyssal Plain. Eos 75, 616.

Sawyer, D.S., Whitmarsh, R.B., Klaus, A. et al. 1994. Proceedings of the Ocean Drilling Program, Initial Reports 149. College Station, TX.

Shillington, D.J., Holbrook, W.S., Avendonk, H.V., Tucholke, B.E., Hopper, J., Louden, K., Larsen, H.C., Nunes, G.T. \& ODP Leg210 Scientific Party 2006. Evidence for asymetric nonvolcanic rifting and slow incipient seafloor spreading from seismic reflection data on the Newfoundland margin. Journal of Geophysical Research 111 B09402.

Sibuet, J.C., Thomas, Y., Marsset, B., Nouze, H., Louvel, V., Savoye, B. \& Le Formal, J.P. 1996. Detailed relationship between tectonics and sedimentation from PARISAR deep-tow seismic data acquired in the Iberia Abyssal Plain. In: Whitmarsh, R.B., Sawyer, D.S., Klaus, A. \& Masson D.G. (eds) Proceedings of the Ocean Drilling Program, Scientific Results, 149, 649-657.

Thinon, I. 1999. Structure profonde de la marge de Gascogne et du Bassin Armoricain. PhD thesis, Bretagne Occidentale University of Brest, France.

Whitmarsh, R.B., Miles, P.R. \& Mauffret, A. 1990a. The ocean-continent boundary off the western continental margin of Iberia - I. Crustal structure at $40^{\circ} 30^{\prime} \mathrm{N}$. Geophysical Journal International 103, 509-531.

Whitmarsh, R.B., Miles, P.R. \& Pinheiro, M. 1990b. The seismic velocity structure of some NE Atlantic continental rise sediments; a lithification index?. Geophysical Journal International 101, 367-378.

Whitmarsh, R.B. \& Miles, P.R. 1995. Models of the development of the West Iberia rifted continental margin at $40^{\circ} 30^{\prime} \mathrm{N}$ deduced from surface and deep-tow magnetic anomalies. Journal of Geophysical Research 100-B3, 3789-3806.

Whitmarsh, R.B. \& Sawyer, D.S. 1996. The ocean-continent transition beneath the Iberia Abyssal Plain and continental rifting to seafloor spreading processes. In: Whitmarsh, R.B., Sawyer, D.S., Klaus, A. \& Masson, D.G. (eds) Proceedings of the Ocean Drilling Program, Scientific Results, 149, 713-733.

Whitmarsh, R. B., Beslier, M.O., Wallace, P.J et al. 1998. Proceedings of the Ocean Drilling Program, Initial Reports 173. College Station, TX.

Whitmarsh, R.B., Manatschal, G. \& Minshull, T.A. 2001. Evolution of magma-poor continental margins from rifting to seafloor spreading. Nature 413, 150-154.

Wilson, R.C.L., Sawyer, D.S., Whitmarsh, R.B., Zerong, J. \& Carbonell J. 1996. Seismic stratigraphy and tectonic history of the Iberia Abyssal Plain. In: Whitmarsh, R.B., Sawyer, D.S., 
Klaus, A. \& Masson, D.G. (eds) Proceedings of the Ocean Drilling Program, Scientific Results, 149, 617-630.

\section{Figure captions}

Fig. 1. Bathymetric Map of the Southern Iberia Abyssal Plain (contours are drawn every 250m) with time migrated seismic reflection profiles used in the study. Thin lines mark the CAM profiles (Discovery 215 Working Group, 1998). Dashed lines mark the SONNE profiles (Roeser at al., 1992), the ISE'97 profiles (Henning et al., 2004) and the IAM9 profile (Pickup et al. 1996). The bold line marks the Lusigal12 profile (Groupe Galice, 1979). Circles represent boreholes of the Ocean Drilling Program Legs 149 and 173. The inset in the lower left corner shows a bathymetric map of the whole Iberia margin and the location of the study area (DGM: Deep Galicia Margin, SIAP: Southern Iberia Abyssal Plain, TAP: Tagus Abyssal Plain).

Fig. 2. Details of the time migrated seismic profiles CAM138 and CAM144 (upper two figures) illustrating the six seismic units determined in the Southern Iberia Abyssal Plain. Lower figure shows a schematic representation of the distribution of the six seismic units in an east-west composite transect across the Southern Iberia Abyssal Plain. Also shown are the location of the ODP sites drilled during Legs 149 and 173.

Fig. 3. Figure 3(a) shows three details of time migrated seismic profiles CAM142, 153, and Sonne16 (s-twtt: seconds two-way travel time) illustrating on the left the three types of deformation structures observed in the post-rift sediments, and on the right the dated reflectors marking limits between the different seismic units. Figure 3(b) shows the distribution of the various deformation structures observed in the post-rift sediments in seismic profiles in a map of the Southern Iberia Abyssal Plain. The bold segments refer to the seismic extracts presented in Figure 3A.

Fig. 4. Basement contour map (interval contour: 100 ms-twtt; ms-twtt: milliseconds two-waytravel-time) of the Southern Iberia Abyssal Plain on which the deformation structures observed in the post-rift sediments are superposed. PR3 and PR4 refer to the peridotite ridges R3 and R4. 1, 2, 3, 4 and 5 refer to particular zones of deformation (cf text for details).

Fig. 5. Extract of the time migrated seismic profile LG12 illustrating a large fold-like structure in the post-rift sedimentary sequence, interpreted as a depositional structure related to deep currents.

Fig. 6. Basement domains and their distribution in the Southern Iberia Abyssal Plain. Figure 6(a): seismic profiles illustrating the five basement domains distinguished in this study with on the right the interpreted basement limit. Figure 6(b): map showing the distribution of the five basement domains defined on seismic profiles in the Southern Iberia Abyssal Plain. PR3 and PR4 refer to the peridotite ridges $\mathrm{R} 3$ and $\mathrm{R} 4$.

Fig. 7. Velocity model for the CAM144 seismic profile established by Chian et al. (1999). The contour interval is $0.2 \mathrm{~km} / \mathrm{s}$. Basement domains limits and ODP drill sites are also indicated.

Fig. 8. Reduced to the pole magnetic anomalies established by Russell and Whitmarsh (2003). The contour interval is $25 \mathrm{nT}$. Basement domains limits and ODP drill sites are indicated on the map. 
Fig. 9. Map showing the distribution of the five basement domains (I to V) and of the domain of the Southern Iberia Abyssal Plain where the deformation localized preferentially (dashed area) (for legend see Fig.3). 
Figure 1 - Péron-Pinvidic et al.

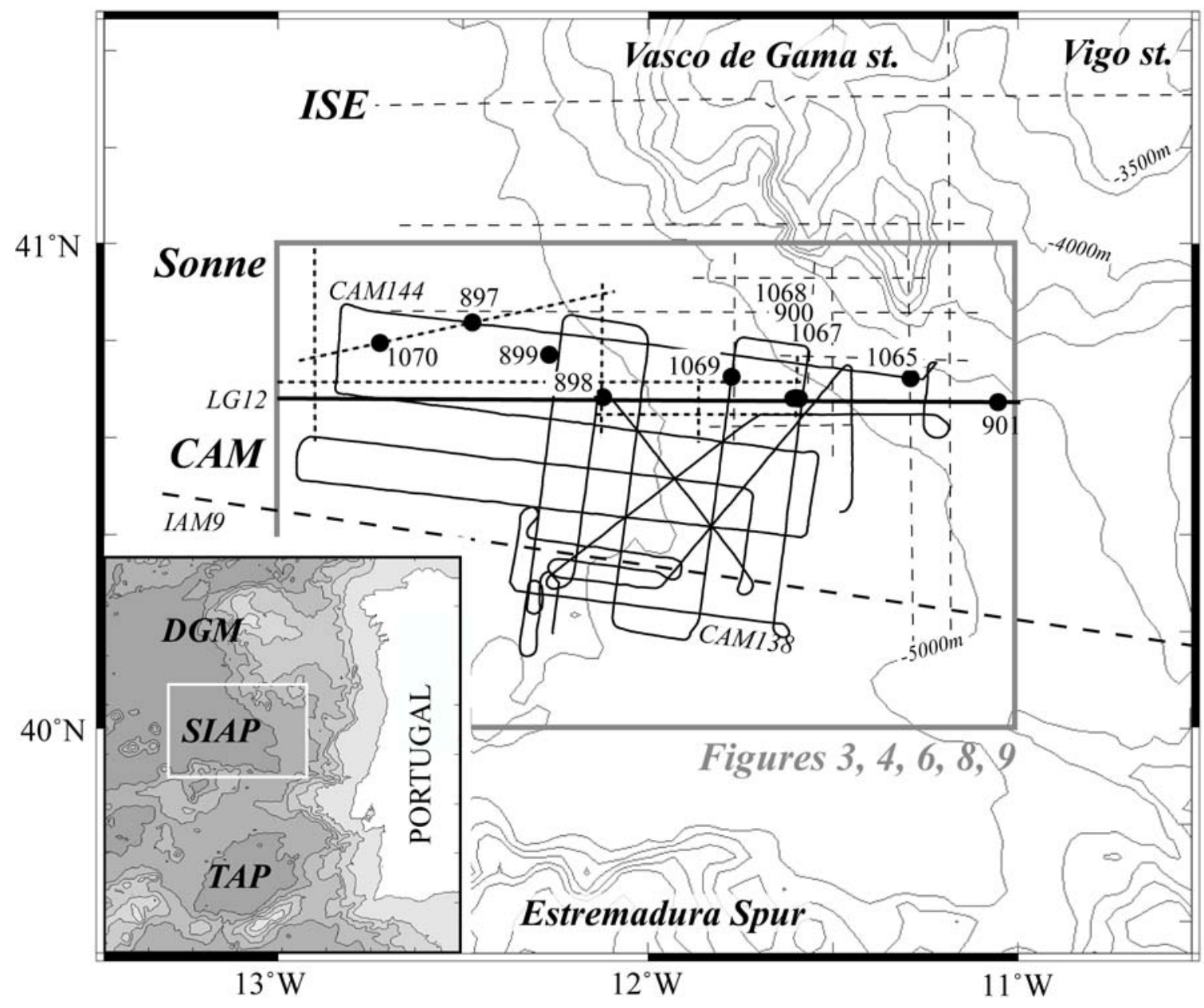


Figure 2 - Péron-Pinvidic et al.
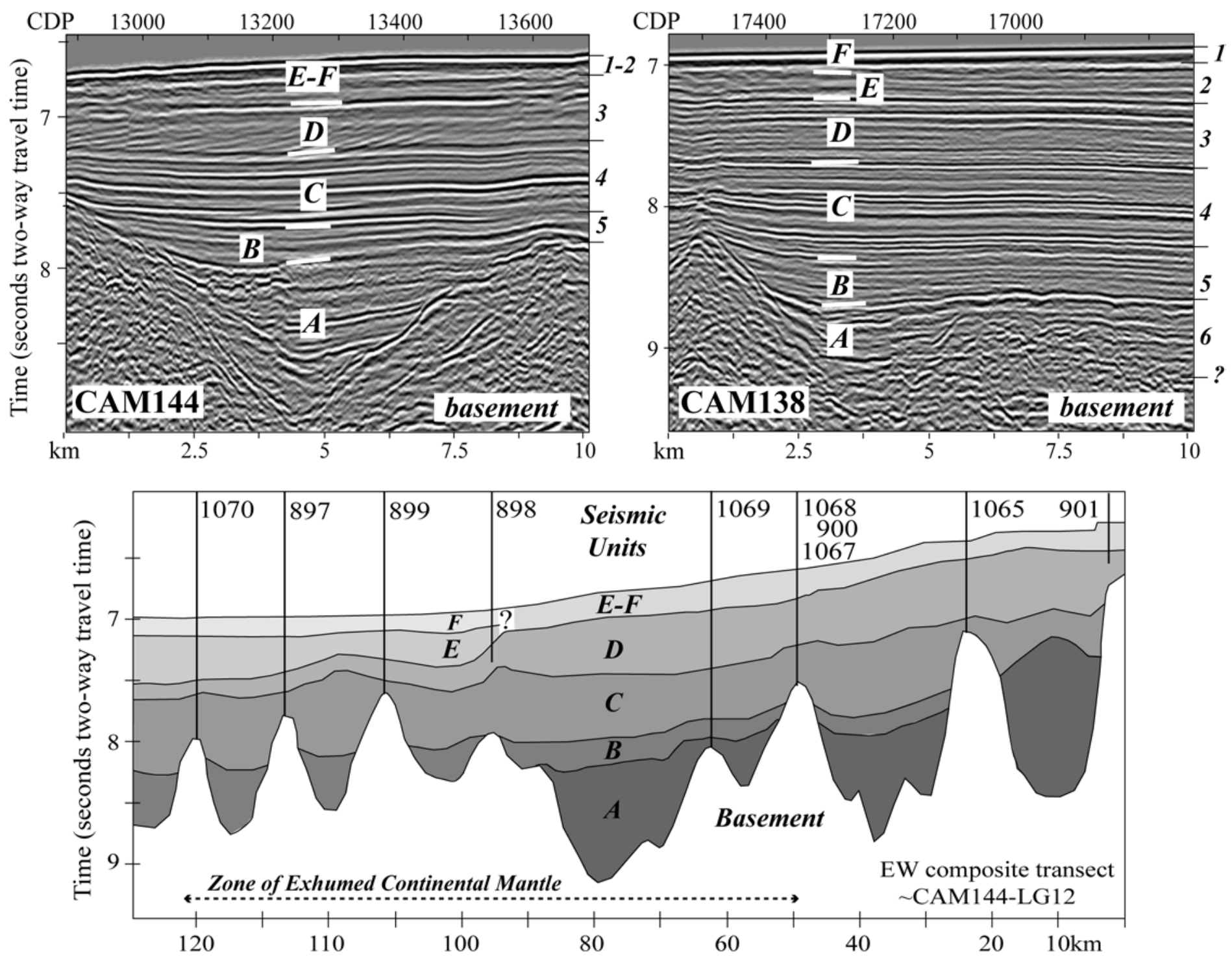
Figure 3 - Péron-Pinvidic et al.

(a)
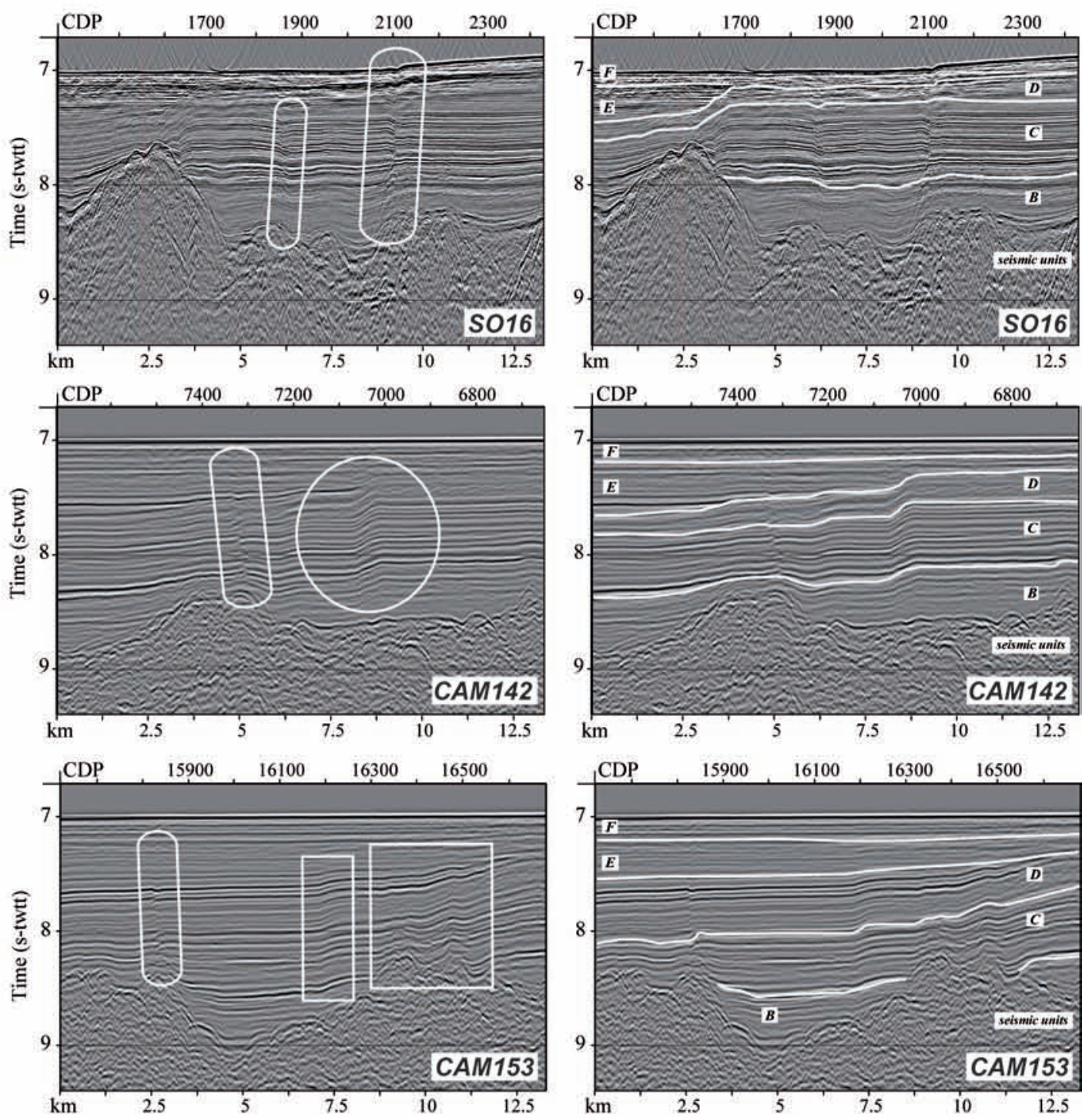

(b)

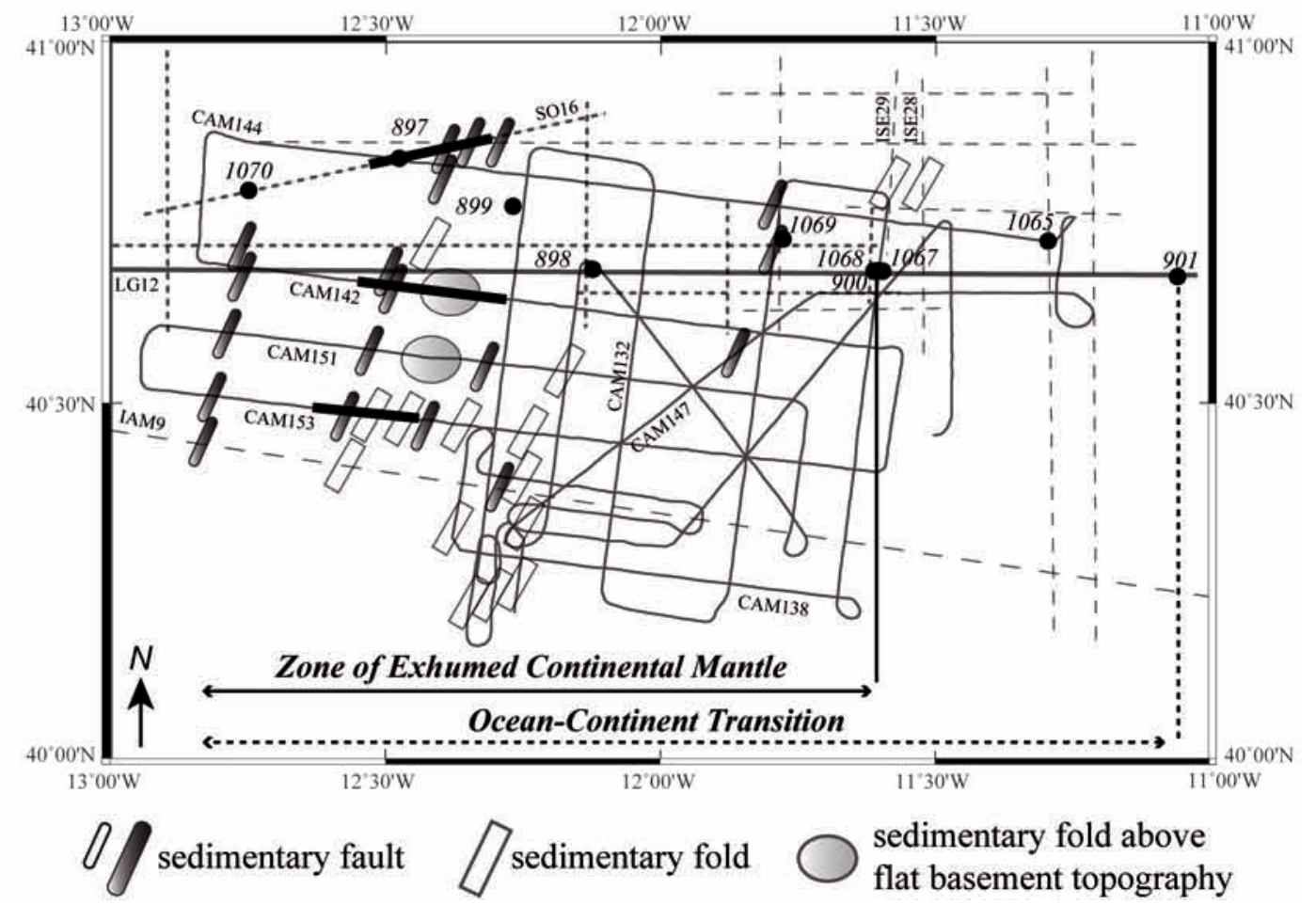


Figure 4 - Péron-Pinvidic et al.

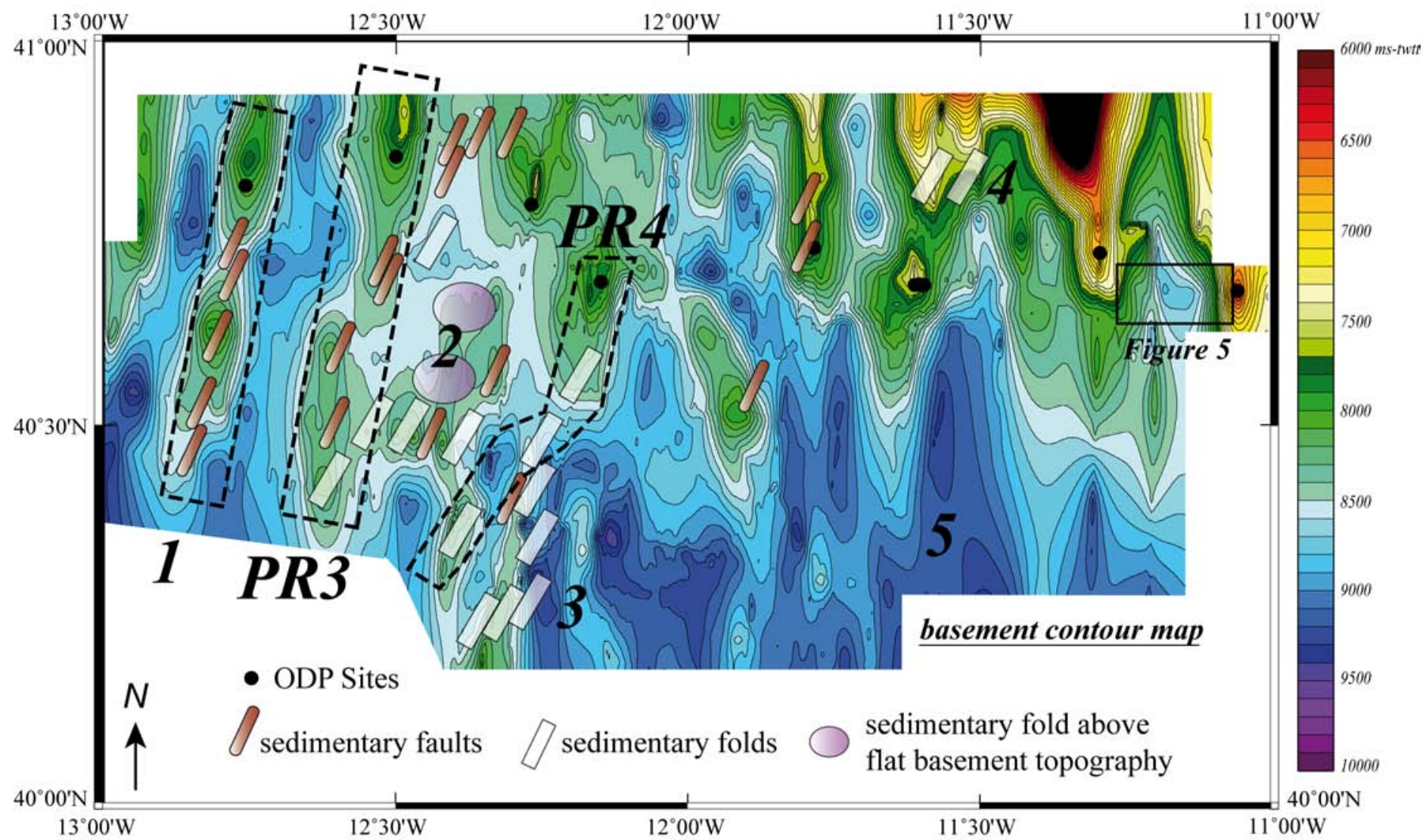


Figure 5 - Péron-Pinvidic et al.

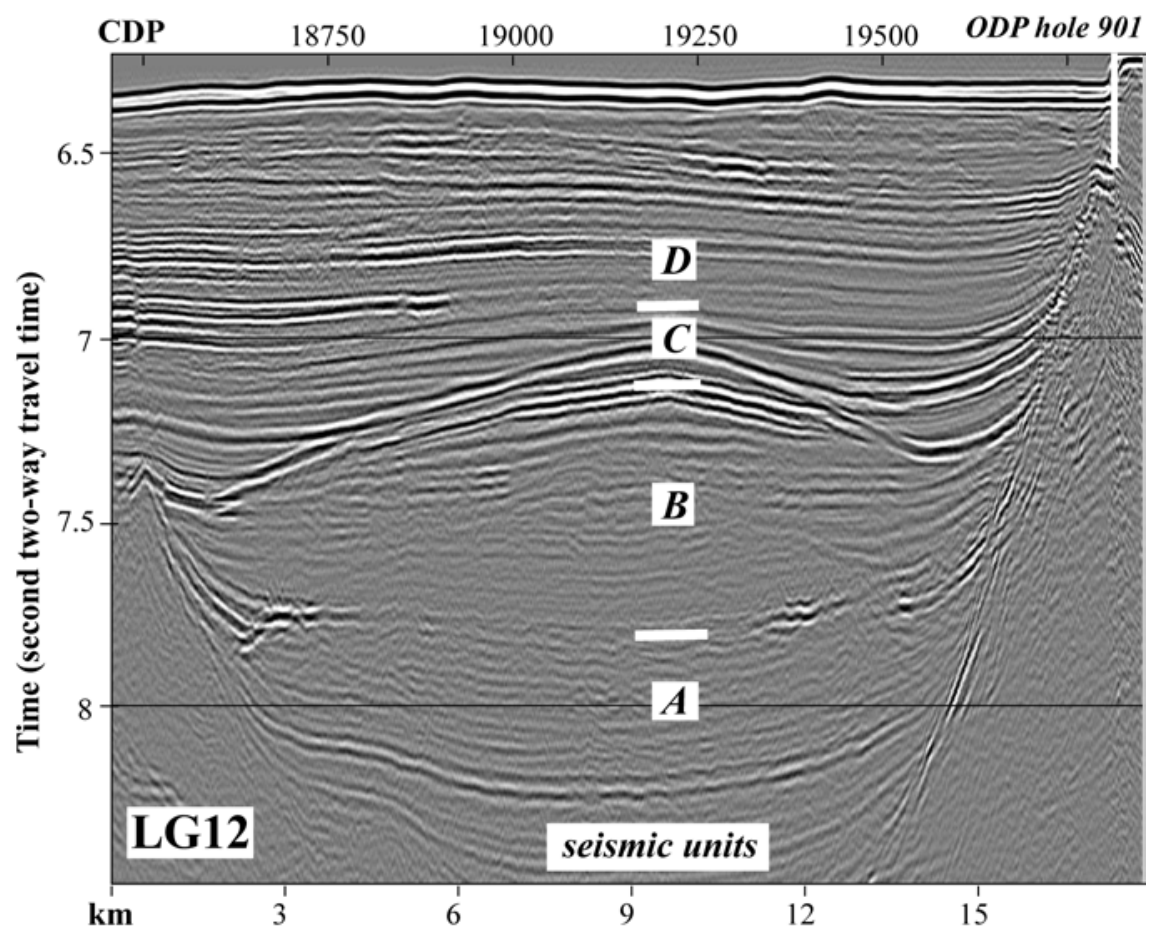


Figure 6 - Péron-Pinvidic et al.

(a)
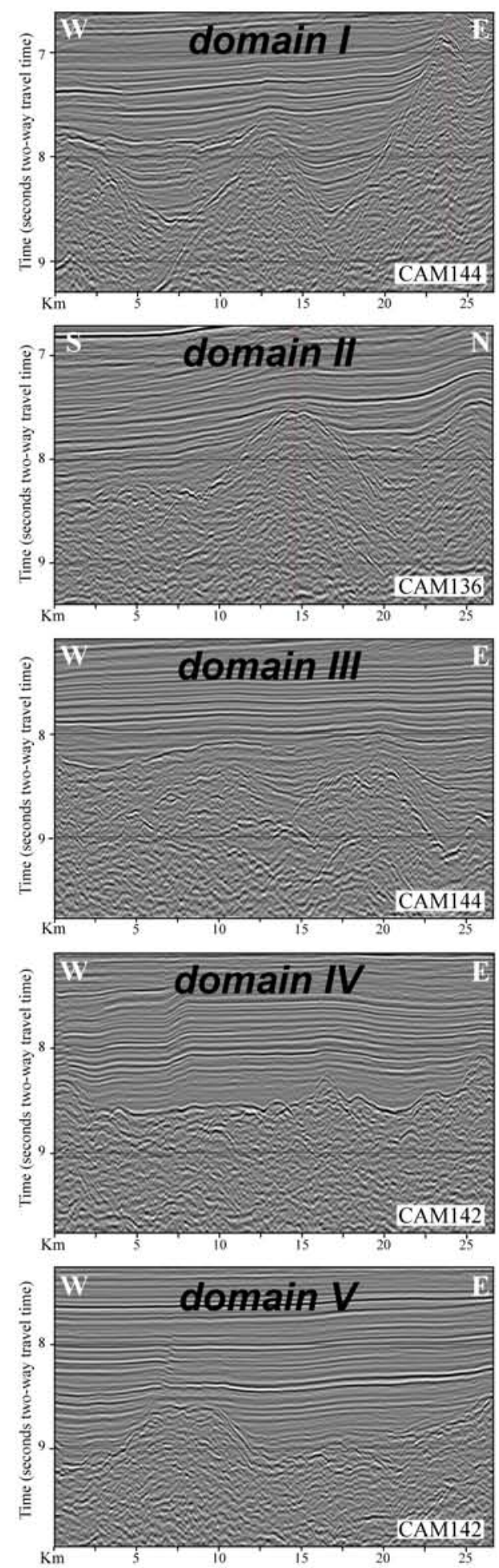
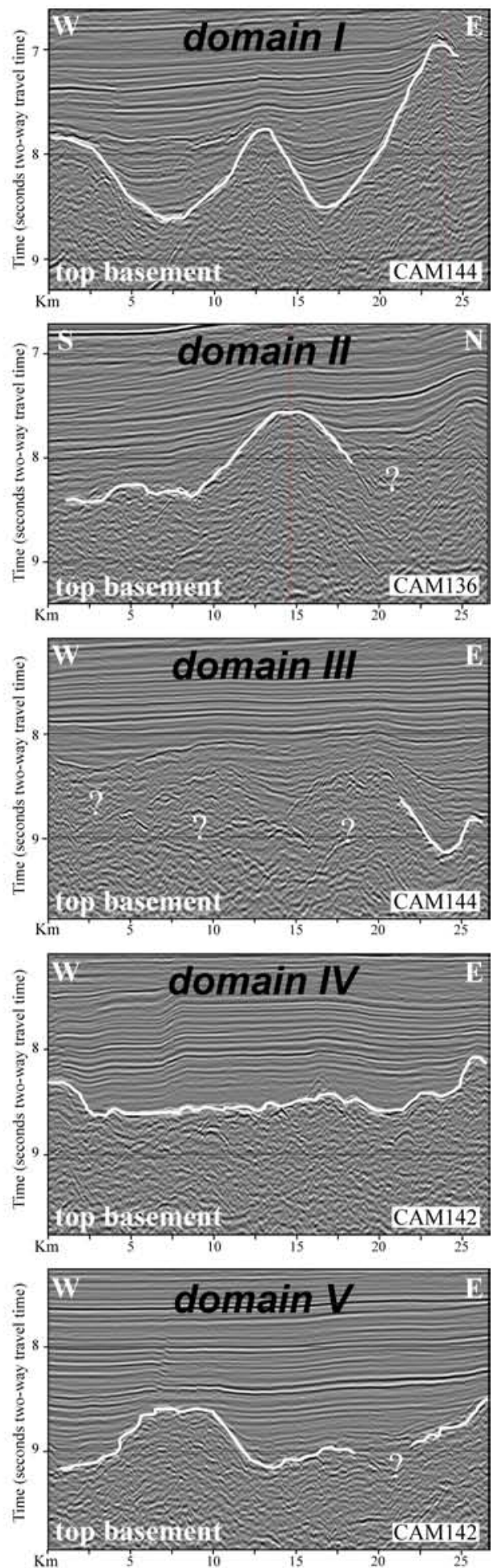

(b)

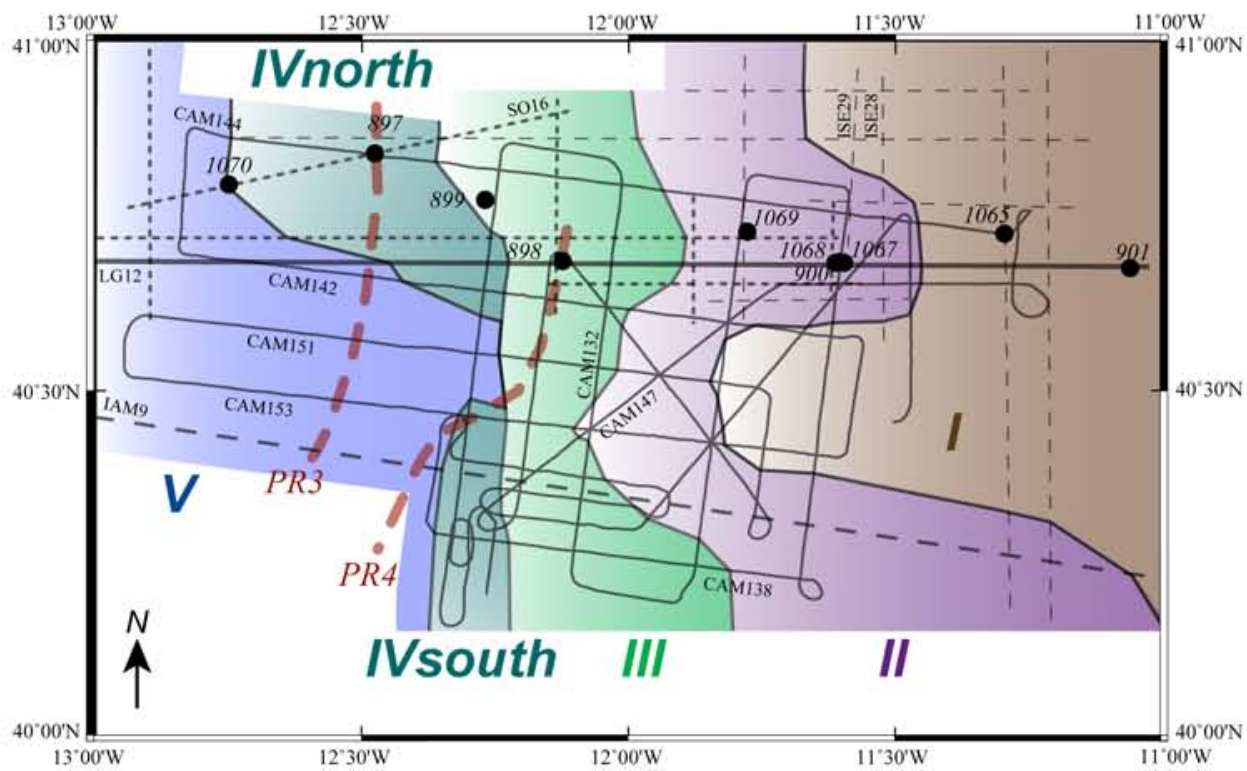


Figure 7 - Péron-Pinvidic et al.

\section{Basement Domains}

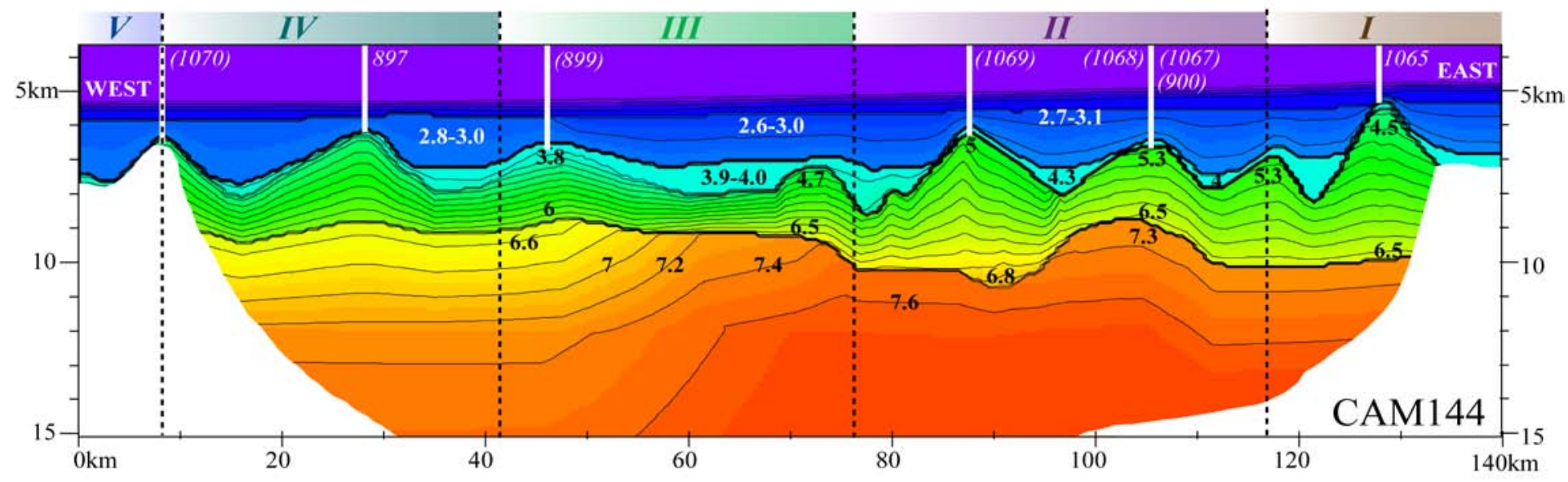


Figure 8 - Péron-Pinvidic et al.

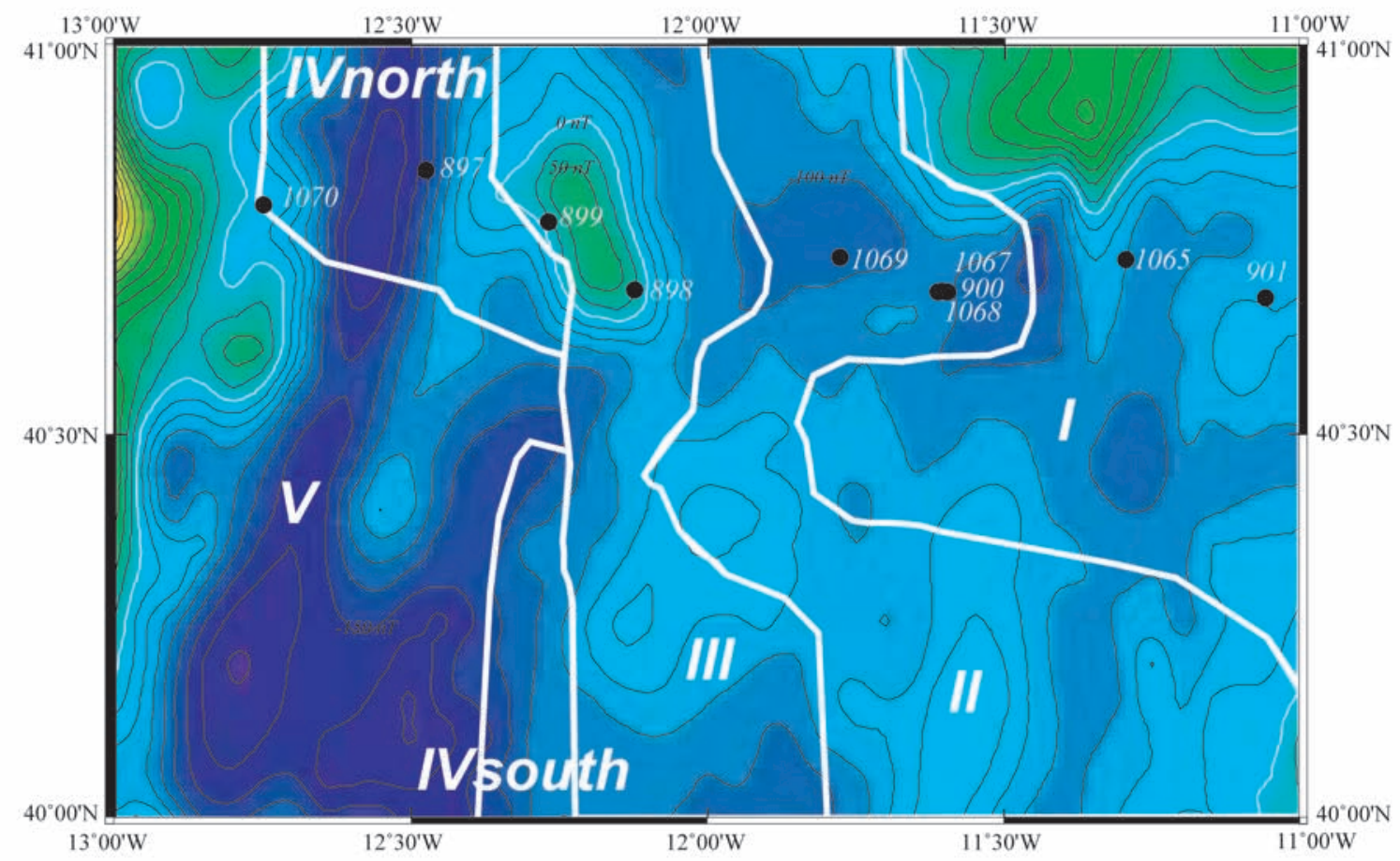


Figure 9 - Péron-Pinvidic et al.

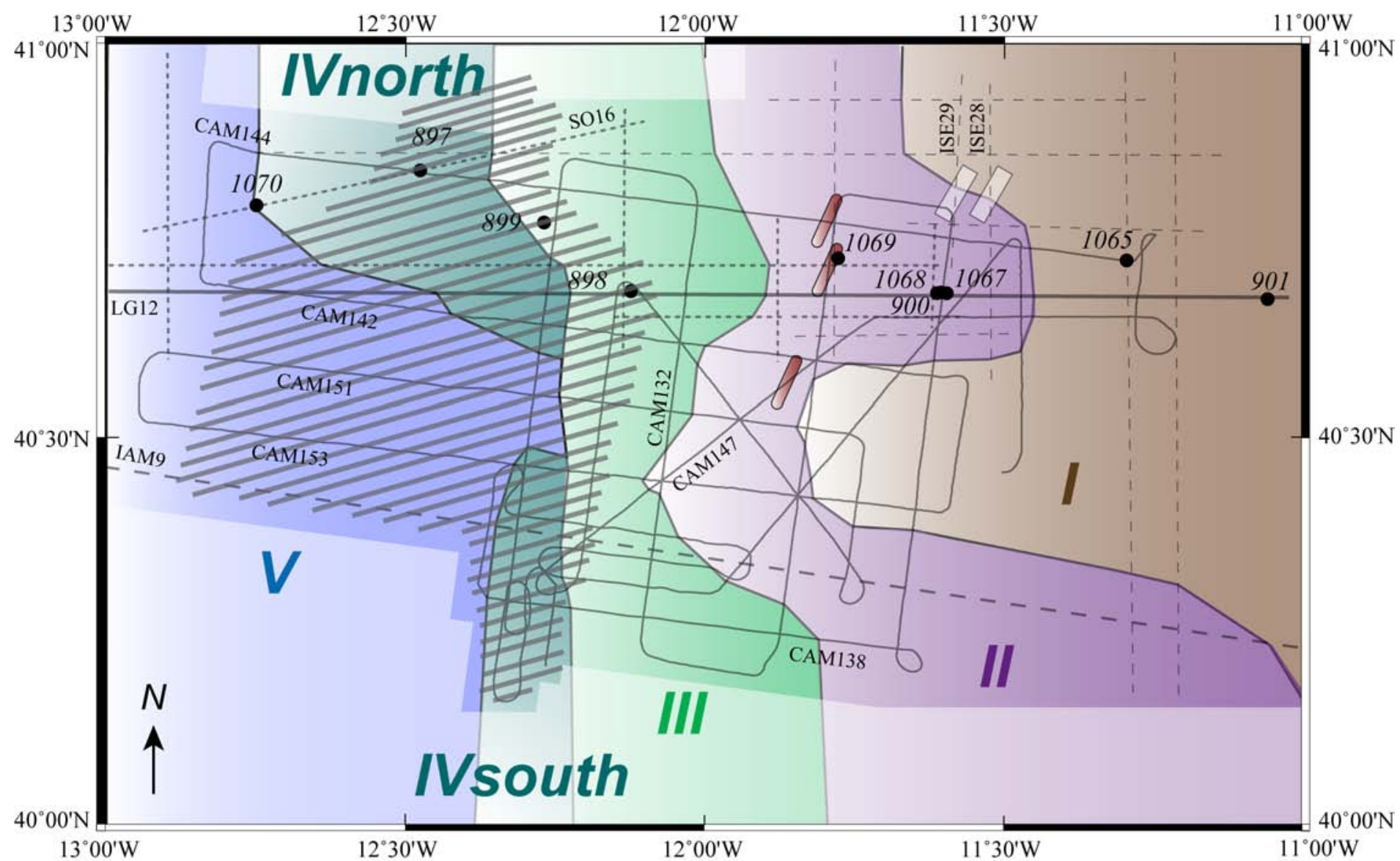

